\title{
Optical Coherence Tomography and Optical Coherence Tomography Angiography Findings in Amblyopic Patients
}

\author{
MARWA S.M. IBRAHIM, M.Sc.*; AZZA M.A. SAID, M.D.**; MAHMOUD A. EL SAMKARY, M.D.** and \\ ISLAM A.M. SOLIMAN, M.D.*
}

The Department of Ophthalmology, Research Institute of Ophthalmology* and Faculty of Medicine, Ain Shams University**

\begin{abstract}
Background: Amblyopia is a unilateral or bilateral decrease of visual acuity caused by deprivation of pattern vision or abnormal binocular interaction, for which no cause can be detected by physical examination of the eye and which in some cases, can be reversed by therapeutic measures.

Aim of Study: To examine amblyopic eyes in a comparative study with age matched controls to detect possible changes in macular, Ganglion cell layer (GCL), choroid, peripapillary retinal nerve fiber layer (RNFL) measurements using optical coherence tomography (OCT), and foveal avascular zone (FAZ) area using optical coherence tomography angiography (OCTA).
\end{abstract}

Patients and Methods: A case control observational study. Forty eyes of forty participants divided into 4 groups. 30 patients with unilateral amblyopia due to strabismus, anisometropia and sensory deprivation (each group included 10 patients) compared with 10 controls. OCT \& OCTA were done using (Heidelberg Engineering, OCT spectralis, Germany).

Results: As regard mean GCL thickness and FAZ area in superficial capillary plexus (SCP) and deep capillary plexus (DCP), there was no statistically significant difference between patients' groups and control group. Also there was no statistically significant difference in RNFL thickness between amblyopic groups and control group except nasal quadrant in strabismic and sensory deprivative groups, there was statistically significant difference. For sub-foveal thickness there was statistically significant difference in strabismic, anisometropic groups, but no significant difference in sensory deprivative group.

Conclusion: Patients with unilateral amblyopia were prone to have a higher central macular thickness in sensory deprivative group only, with no difference in thickness regarding other groups, and thinner nasal quadrant RNFL thickness in strabismic and sensory deprivative groups only, when compared to control eyes.

Key Words: Optical coherence tomography-Optical coherence tomography angiography - Ganglion cell layer - Retinal nerve fiber layer - Superficial capillary plexus - Deep capillary plexus.

Correspondence to: Dr. Marwa S.M. Ibrahim, E-Mail: salahmarwa477@gmail.com

\section{Introduction}

AMBLYOPIA is the most common vision deficit in children, affecting $2-5 \%$ of children in the UK and the second most common cause of functional low vision in children in low income countries. Unilateral amblyopia is a developmental defect of vision, and has two main causes: (1) A difference in the optical properties of the two eyes, reflected in a different spectacle prescription for the right and the left eye (anisometropia) and (2) Strabismus (misalignment of the visual axes). Some children have both anisometropic and strabismic amblyopia ('combined' or 'mixed mechanism' amblyopia) [1]

Rarely, congenital or early childhood obstruction of the visual axis, for example by lid ptosis or by opacities of the cornea, crystalline lens or vitreous, can give rise to amblyopia by deprivation, as the retina does not receive a clear image [1].

Although it has been reported that amblyopia primarily causes cerebral anatomical alterations in lateral geniculate bodies and the visual cortex, it can also affect retinal layers and vascular structures [2]. Contrary to the general belief that the amblyopic eyes are structurally normal, significant alterations have been found in the rerinal nerve fiber layer (RNFL), ganglion cell layer (GCL) and foveal thickness in patients with amblyopia. However, a consensus on retinal abnormalities has not been reached [3]. Optical coherence tomography (OCT) is a non-invasive and non-contact type of fundus imaging with high repeatability and reliability that is not influenced by uncorrected refractive errors or illumination conditions. Therefore, OCT has been described as a useful tool in presenting subtle macular pathologies [4].

Optical coherence tomography angiography (OCTA) is a non-invasive diagnostic imaging tech- 
nique. It provides images of the retinal vasculature in a few seconds without the need to use a dye, eliminating the risk of allergic reactions and patient discomfort [5]. OCT-A obtains images of the retinal vessels by comparing the signals of a series of consecutive B-scans performed at the same location [6]. The temporal evolution of the optical coherence tomography (OCT) signal, caused by the motion of scattering particles such as erythrocytes within vessels, allows the visualization of functional blood vessels [5]. Furthermore, OCT-A is able to examine the size and the contour of the foveal avascular zone (FAZ) [7].

\section{Aim of the work:}

To compare amblyopic eyes with age matched control eyes to detect possible changes in macular, GCL, choroid and peripapillary RNFL measurements using OCT and FAZ area using OCTA.

\section{Patients and Methods}

This study is a case control observation study it included 40 eyes of 40 patients attending outpatient clinic of Ophthalmology Department of Research Institute of Ophthalmology in Giza, from the period October 2020 till December2020. Those patients were asked to participate and were enrolled in this study. The ethical standards stated by the ethical committee of Ain Shams University hospitals, were followed. All participants underwent, full ophthalmological examination including manifest and cycloplegic refraction using (Topcon Auto-refractometer RM 8900). Uncorrected visual acuity (UCVA) and best corrected visual acuity (BCVA) using Snellen's chart, with conversion to logarithm of minimal angle of resolution (LogMAR) for statistical analysis. An eye was classified as being amblyopic when the BCVA in one eye was at least two Snellen visual acuity lines worse than the fellow eye, and the anisometropia was defined as an inter-ocular difference in refraction of at least 1.5 diopters (D). Cover, cover-uncover, alternate cover test and extraocular muscle movements were examined. Anterior segment examination with slit lamp biomicroscopy. Posterior segment examination with indirect slit lamp biomicroscopy using (Volk +90 lens), and indirect ophthalmoscope using (+20 D lens) was done.

Inclusion criteria were age between 7-18 years and amblyopia in one eye due to strabismus, anisometropia or sensory deprivation. We excluded patients with history of prematurity, trauma, neurologic disease, or systemic conditions that could alter the microvasculature (including diabetes, hypertension, cardiovascular disease, and renal disease), uncooperative patients, those with poor fixation and patients with refractive errors more than $6 \mathrm{D}$.

Patients were divided into four groups: Group (I): Control group (10 patients). Group (II): Strabismic amblyopia (10 patients). Group (III): Anisometropic hypermetropic amblyopia (10 patients). Group (IV): Sensory deprivation (10 patients).

OCT was done to measure the macular, GCL, peripapillary RNFL, and choroid thickness \& OCTA was done to measure FAZ area using (Heidelberg engineering, OCT spectralis, Germany).

\section{Macula scan:}

OCT images were generated by the fast volume scan: $20^{\circ} \times 20^{\circ}(6 \times 6 \mathrm{~mm})$ raster scans consisting of 25 horizontal lines. For each horizontal line, nine B-scans were averaged with the automatic realtime mode to reduce speckle noise. Whereas scans with significant image artifacts were excluded. The retinal thickness in each frame was calculated as the distance between the first signal from the vitreo-retinal interface and the signal from the outer border of the retinal pigment epithelium (RPE). Spectralis OCT provides a circular map analysis in which the average thickness is displayed as a color code or numeric values in the nine Early Treatment Diabetes Retinopathy Study (ETDRS) areas. The ETDRS map consists of three concentric rings with diameters of $1 \mathrm{~mm}$ (central), $3 \mathrm{~mm}$ (inner), and $6 \mathrm{~mm}$ (outer), the inner and outer rings are divided into four areas. All these measurements were calculated automatically by the software in different planes. Macula map for measurement of total thickness and GCL.

\section{Optic disc and peripapillary RNFL scan:}

Using SD-OCT (Spectralis) with a $3.46 \mathrm{~mm}$ diameter scan circle centered on the optic disc, the Spectralis OCT software allows for automatic segmentation of the upper and lower borders of the RNFL to calculate the average RNFL thickness. Peripapillary RNFL thickness values are divided into 4 quadrants, namely superior, inferior, nasal and temporal.

\section{Choroidal thickness:}

The SD-OCT with enchanced depth imagining (EDI) system was used to measure Choroidal thickness. Choroidal thickness was manually measured at fovea, 1 and $3 \mathrm{~mm}$ nasally and temporally using horizontal line scans from 9am to $12 \mathrm{pm}$ to avoid diurnal variation. The choroid was measured from the outer portion of the hyper-reflective line corre- 
sponding to the RPE to the inner surface of the sclera.

OCTA:

A rectangular $10 \mathrm{~mm} X 5 \mathrm{~mm}$ area macular scan protocol was applied. OCTA of the superficial and deep networks were captured. Each scan was automatically segmented to visualize the retinal superficial capillary plexus (SCP) and deep capillary plexus (DCP). SCP OCTA images were segmented with the inner boundary at the internal limiting membrane (ILM) and the outer boundary at $10 \mathrm{~m}$ bove the inner plexiform layer (IPL). DCP images were segmented with an inner boundary 10 ove the IPL and the outer boundary $10 \mathrm{mblow}$ the outer plexiform layer (OPL). FAZ area was measured at both the superficial and deep capillary plexus, using software "Draw region" tool to outline FAZ area manually, and software automatically calculate the outlined area.

\section{Statistical analysis:}

Data were collected, revised, coded and entered to the Statistical Package for Social Science (IBM SPSS) version 23. The quantitative data were presented as mean, standard deviations and ranges when their distribution found parametric. Also qualitative variables were presented as number and percentages. The measurement of inter observer reliability of FAZ area calculations were tested by using Intraclass correlation coefficients (ICCs). The comparison between two independent groups with quantitative data and parametric distribution were done by using Independent $t$-test.
The confidence interval was set to $95 \%$ and the margin of error accepted was set to 5\%. So, the $p$ value was considered significant as the following:

- $p$-value $>0.05$ : Non significant (NS).

- $p$-value $<0.05$ : Significant $(\mathrm{S})$.

- $p$-value <0.01: Highly significant (HS).

\section{Results}

This study included total of 40 eyes of 40 patients divided into four groups: Group (I): Control group (10 patients). Group (II): Strabismic amblyopia (10 patients). Group (III): Anisometropic hypermetropic amblyopia (10 patients). Group (IV): Sensory deprivation (10 patients). With a mean age of $10.50 \pm 1.72$ for control group and $11.83 \pm 3.11$ for amblyopic patients. In control group 6 eyes belonged to 6 males and the other 4 eyes belonged to 4 females, while in amblyopic patients group 10 eyes belonged to 10 males and the other 20 eyes belonged to 20 females. The base characteristics of the studied groups are summarized in (Table 1). There was no significant statistical difference between these groups in terms of age and sex.

The mean BCVA $( \pm$ SD) recorded using Log. MAR in control group was $(0.0 \pm 0.0)$, while in strabismic, anisometropic and sensory deprivative groups were $0.38 \pm 0.14,0.41 \pm 0.23$ and $0.51 \pm 0.23$ respectively. There was statistically significant difference found between control group and the three amblyopic groups regarding BCVA ( $p$-value $<0.001$ ). (Table 2).

\begin{tabular}{|c|c|c|c|c|c|c|c|}
\hline & \multicolumn{2}{|c|}{$\begin{array}{c}\text { Control group } \\
\text { No. }=10\end{array}$} & \multicolumn{2}{|c|}{$\begin{array}{l}\text { Patients group } \\
\text { No. }=30\end{array}$} & Test value & $p$-value & Sig \\
\hline $\begin{array}{l}\text { Age: } \\
\quad \text { Mean } \pm \text { SI } \\
\text { Range }\end{array}$ & \multicolumn{2}{|c|}{$\begin{array}{l}10.50 \pm 1.72 \\
8-14\end{array}$} & & $\begin{array}{l}1.83 \pm 3.11 \\
17\end{array}$ & $-1.285 \bullet$ & 0.206 & NS \\
\hline $\begin{array}{l}\text { Sex: } \\
\quad \text { Male } \\
\quad \text { Female }\end{array}$ & \multicolumn{2}{|c|}{$\begin{array}{ll}6 & (60.0 \%) \\
4 & (40.0 \%)\end{array}$} & & $\begin{array}{l}(33.3 \%) \\
(66.7 \%)\end{array}$ & $2.222 *$ & 0.136 & NS \\
\hline $\begin{array}{l}\text { Eye: } \\
\text { Right } \\
\text { Left }\end{array}$ & \multicolumn{2}{|c|}{$\begin{array}{ll}10 & (100.0 \%) \\
0 \quad(0.0 \%)\end{array}$} & & $\begin{array}{l}(33.3 \%) \\
(66.7 \%)\end{array}$ & $13.333^{*}$ & 0.000 & HS \\
\hline \multicolumn{8}{|c|}{$\begin{array}{l}p \text {-value }>0.05: \text { Non significant }(\mathrm{NS}) . \\
p \text {-value }<0.01 \text { : Highly significant }(\mathrm{HS}) * \text {-value }<0.05 \text { : Significant }(\mathrm{S}) \\
\end{array}$} \\
\hline VA & $\begin{array}{l}\text { Control group } \\
\text { No. }=10\end{array}$ & $\begin{array}{l}\text { Strab } \\
\text { ambl } \\
\text { No. }\end{array}$ & & $\begin{array}{c}\text { Anisometropic } \\
\text { amblyopia } \\
\text { No. }=10\end{array}$ & $\begin{array}{r}\text { Sensory } \\
\text { amb } \\
\text { No. }\end{array}$ & $\begin{array}{l}\text { rivative } \\
\text { pia } \\
10\end{array}$ & $p$-value \\
\hline $\begin{array}{l}\text { Mean } \pm \text { SD } \\
\text { Range }\end{array}$ & $\begin{array}{l}0.00 \pm 0.00 \\
0-0\end{array}$ & $\begin{array}{l}0.38 \\
0.2-0\end{array}$ & & $\begin{array}{l}0.41 \pm 0.23 \\
0.2-1\end{array}$ & $\begin{array}{l}0.51 \\
0.3-1\end{array}$ & & $<0.001$ \\
\hline
\end{tabular}

$p$-value $>0.05$ : Non significant (NS). $\quad p$-value $<0.05$ : Significant. $\bullet$ : One Way ANOVA test. 


\section{Structural OCT data:}

\section{Total macular thickness:}

Comparison was done between control group and patients' group as regards mean total macular thickness in the central $(1 \mathrm{~mm})$ and in the four quadrants (at $3 \mathrm{~mm}$ and $6 \mathrm{~mm}$ ) and revealed that there was no statistically significant difference ( $p$ values were $>0.05$ ) except for central macular thickness in sensory deprivative group there was significant increase in thickness compared to control group with $p$-value 0.033 (Table 3 ).

\section{Ganglion cell layer:}

Comparison was done between control group and patients' group as regard mean GCL thickness in the central $(1 \mathrm{~mm})$, and in the four quadrants (at
$3 \mathrm{~mm}$ and $6 \mathrm{~mm}$ ) and revealed that there was no statistically significant difference in all quadrants $(p$-values were $>0.05)$ (Table 4$)$.

\section{Retinal nerve fiber layer:}

Comparison between control group and patients' group was done regarding RNFL thickness and revealed non statistically significant difference in all quadrants in patients with anisometropic amblyopia, also in strabismic and deprivative groups there was no statistically significant difference in superior, inferior and temporal quadrants ( $p$-value $>0.05$ ). A statistically significant thinner nasal quadrant was found in strabismic and sensory deprivative groups ( $p$-value $0.011, p$-value 0.015 respectively) (Table 5).

Table (3): Comparison between control group and patients' group regarding total macular thickness.

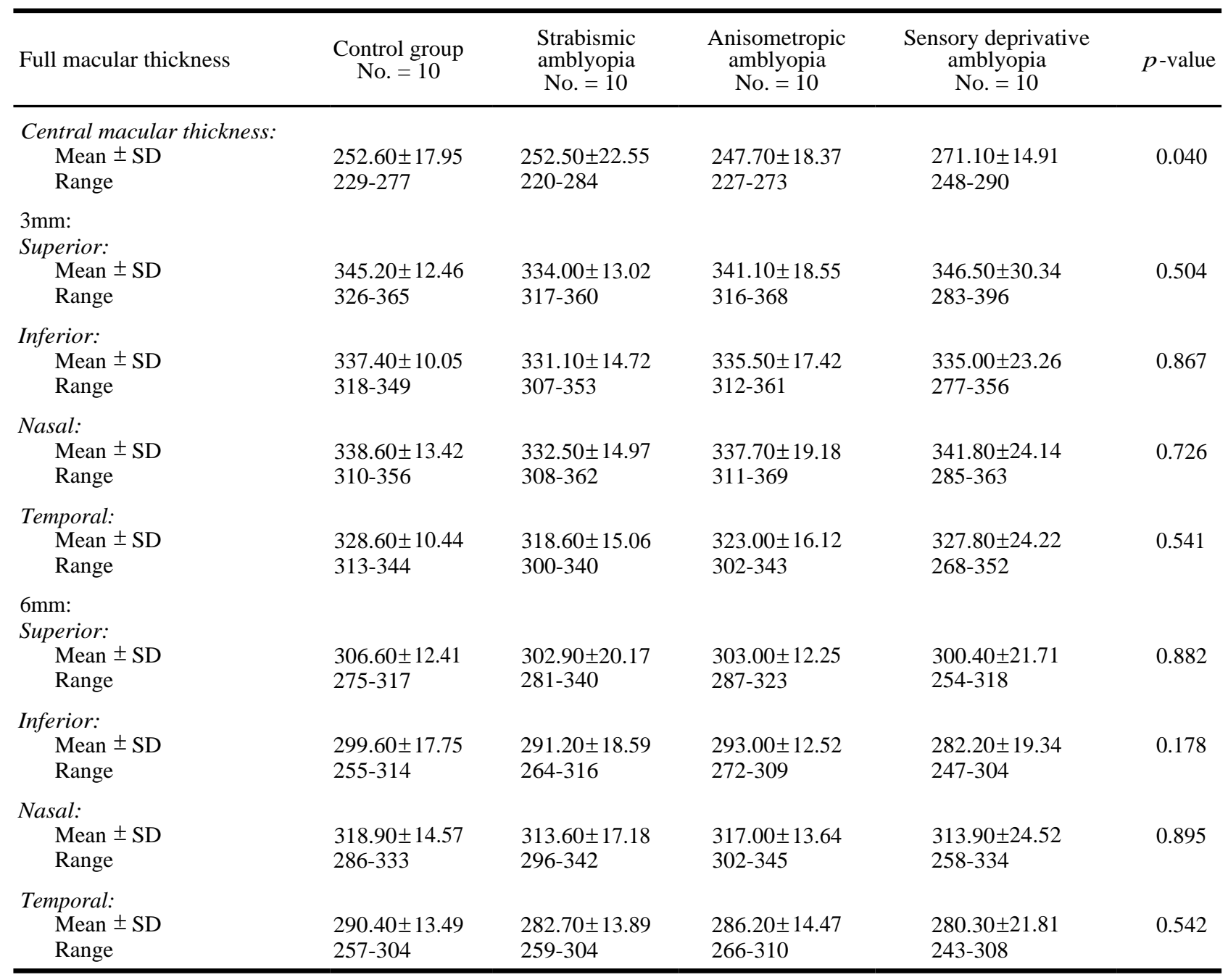

$p$-value $>0.05$ : Non significant (NS).

$p$-value <0.05: Significant (S)

$\bullet$ One Way ANOVA test. 
Table (4): Comparison between control group and patients groups regarding GCL.

\begin{tabular}{|c|c|c|c|c|c|}
\hline GCL thickness & $\begin{array}{l}\text { Control group } \\
\text { No. }=10\end{array}$ & $\begin{array}{c}\text { Strabismic } \\
\text { amblyopia } \\
\text { No. }=10\end{array}$ & $\begin{array}{c}\text { Anisometropic } \\
\text { amblyopia } \\
\text { No. }=10\end{array}$ & $\begin{array}{c}\text { Sensory deprivative } \\
\text { amblyopia } \\
\text { No. }=10\end{array}$ & $p$-value \\
\hline \multicolumn{6}{|l|}{ GCL thickness: } \\
\hline Mean \pm SD & $12.00 \pm 3.13$ & $14.10 \pm 5.36$ & $12.70 \pm 3.43$ & $15.30 \pm 3.65$ & 0.271 \\
\hline Range & $7-17$ & $7-23$ & $7-17$ & $9-22$ & \\
\hline \multicolumn{6}{|l|}{$3 \mathrm{~mm}:$} \\
\hline \multicolumn{6}{|l|}{ Superior: } \\
\hline Mean \pm SD & $54.30 \pm 2.67$ & $49.60 \pm 6.11$ & $52.90 \pm 5.65$ & $52.70 \pm 10.77$ & 0.493 \\
\hline Range & $49-58$ & $38-59$ & $40-58$ & $24-61$ & \\
\hline \multicolumn{6}{|l|}{ Inferior: } \\
\hline Mean \pm SD & $52.80 \pm 3.82$ & $50.60 \pm 5.13$ & $52.50 \pm 2.80$ & $50.30 \pm 10.67$ & 0.751 \\
\hline Range & $47-60$ & $44-59$ & $47-56$ & $22-60$ & \\
\hline \multicolumn{6}{|l|}{ Nasal: } \\
\hline Mean \pm SD & $51.50 \pm 4.33$ & $48.50 \pm 5.72$ & $51.70 \pm 3.97$ & $51.30 \pm 11.33$ & 0.708 \\
\hline Range & $41-56$ & $40-57$ & $46-59$ & $21-60$ & \\
\hline \multicolumn{6}{|l|}{ Temporal: } \\
\hline Mean \pm SD & $48.40 \pm 3.37$ & $45.00 \pm 6.85$ & $47.40 \pm 3.44$ & $45.70 \pm 10.04$ & 0.642 \\
\hline Range & $42-52$ & $31-52$ & $42-52$ & $21-56$ & \\
\hline \multicolumn{6}{|l|}{$6 \mathrm{~mm}:$} \\
\hline \multicolumn{6}{|l|}{ Superior: } \\
\hline Mean \pm SD & $38.10 \pm 3.38$ & $35.60 \pm 4.55$ & $35.00 \pm 3.13$ & $34.80 \pm 6.14$ & 0.337 \\
\hline Range & $32-43$ & $30-44$ & $31-39$ & $20-41$ & \\
\hline \multicolumn{6}{|l|}{ Inferior: } \\
\hline Mean \pm SD & $37.20 \pm 6.53$ & $35.30 \pm 5.50$ & $35.50 \pm 4.22$ & $30.70 \pm 4.60$ & 0.055 \\
\hline Range & $27-47$ & $27-47$ & $30-42$ & $24-36$ & \\
\hline \multicolumn{6}{|l|}{ Nasal: } \\
\hline Mean \pm SD & $39.60 \pm 4.53$ & $38.60 \pm 3.60$ & $39.40 \pm 2.95$ & $36.70 \pm 6.04$ & 0.455 \\
\hline Range & $31-46$ & $34-46$ & $34-44$ & $24-44$ & \\
\hline \multicolumn{6}{|l|}{ Temporal: } \\
\hline Mean \pm SD & $39.20 \pm 4.26$ & $34.40 \pm 7.35$ & $37.40 \pm 5.23$ & $32.10 \pm 7.53$ & 0.072 \\
\hline Range & $30-45$ & $23-47$ & $32-47$ & $22-43$ & \\
\hline
\end{tabular}

$p$-value $>0.05$ : Non significant (NS). $\quad p$-value $<0.05$ : Significant $(\mathrm{S}) . \quad p$-value $<0.01$ : Highly significant $(\mathrm{HS}) . \bullet:$ One Way ANOVA test.

Table (5): Showing RNFL comparison between control group and amblyopic groups

\begin{tabular}{|c|c|c|c|c|c|c|c|}
\hline RNFL & $\begin{array}{l}\text { Control group } \\
\text { No. }=10\end{array}$ & $\begin{array}{c}\text { Strabismic } \\
\text { amblyopia } \\
\text { No. }=10\end{array}$ & $\begin{array}{l}\text { Anisometropic } \\
\text { amblyopia } \\
\text { No. }=10\end{array}$ & $\begin{array}{c}\text { Sensory deprivative } \\
\text { amblyopia } \\
\text { No. }=10\end{array}$ & $\begin{array}{c}\text { Test } \\
\text { value }\end{array}$ & $\begin{array}{c}p- \\
\text { value }\end{array}$ & Sig. \\
\hline \multicolumn{8}{|l|}{ Superior: } \\
\hline Mean \pm SD & $125.40 \pm 13.87$ & $118.40 \pm 20.71$ & $138.10 \pm 13.35$ & $115.90 \pm 31.55$ & 2.206 & 0.104 & NS \\
\hline Range & $110-157$ & $85-153$ & $105-156$ & $45-157$ & & & \\
\hline \multicolumn{8}{|l|}{ Inferior: } \\
\hline Mean \pm SD & $132.00 \pm 10.65$ & $127.30 \pm 18.65$ & $148.90 \pm 18.35$ & $130.40 \pm 39.01$ & 1.622 & 0.201 & NS \\
\hline Range & $116-150$ & $103-155$ & $113-173$ & $44-191$ & & & \\
\hline \multicolumn{8}{|l|}{ Nasal: } \\
\hline Mean \pm SD & $85.20 \pm 13.16$ & $68.30 \pm 12.57$ & $91.20 \pm 10.75$ & $69.00 \pm 18.87$ & 6.651 & 0.001 & HS \\
\hline Range & $64-100$ & $51-90$ & $75-106$ & $30-94$ & & & \\
\hline \multicolumn{8}{|l|}{ Temporal: } \\
\hline Mean \pm SD & $77.60 \pm 9.43$ & $71.70 \pm 13.28$ & $72.30 \pm 4.95$ & $72.70 \pm 18.94$ & 0.455 & 0.716 & NS \\
\hline Range & $62-97$ & $50-88$ & $63-78$ & $25-97$ & & & \\
\hline
\end{tabular}

$p$-value $>0.05$ : Non significant (NS). $\quad p$-value $<0.05$ : Significant $(\mathrm{S}) . \quad p$-value $<0.01$ : Highly significant (HS). 


\section{Choroidal thickness (Table 6) (Fig. 1):}

Comparison between control group and patients' group was done regarding Choroidal thickness at subfovea, $1 \mathrm{~mm}$ and $3 \mathrm{~mm}$ (nasal \& temporal) and revealed the following:

For subfoveal thickness there was statistically significant difference in strabismic, anisometropic groups ( $p$-value $0.031, p$-value 0.001 respectively) and no statistically significant difference in Sensory deprivative group ( $p$-value 0.0073 ).

At nasal $1 \mathrm{~mm}$ there was statistically significant difference in strabismic, anisometropic and sensory deprivative groups ( $p$-value $0.023, p$-value 0.007 , $p$-value 0.027 respectively). And for temporal $1 \mathrm{~mm}$ there was no statistically significant difference in strabismic and sensory deprivative group ( $p$-value $0.053, p$-value 0.050 respectively) and statistically significant difference in anisometropic group ( $p$ value 0.004 )

At temporal $3 \mathrm{~mm}$ there was no statistically significant difference in all patients' group ( $p$-value $>0.05$ ). For nasal thickness at $3 \mathrm{~mm}$ there was no statistically significant difference in strabismic and sensory deprivative group ( $p$-value $0.077, p$ value 0.205 respectively) and statistically significant difference in anisometropic group ( $p$-value $0.005)$.

Table (6): Comparing choroidal thickness between control group and amblyopic group.

\begin{tabular}{|c|c|c|c|c|c|c|c|}
\hline $\begin{array}{l}\text { Choroidal } \\
\text { thickness }\end{array}$ & $\begin{array}{l}\text { Control group } \\
\text { No. }=10\end{array}$ & $\begin{array}{l}\text { Strabismic } \\
\text { amblyopia } \\
\text { No. }=10\end{array}$ & $\begin{array}{c}\text { Anisometropic } \\
\text { amblyopia } \\
\text { No. }=10\end{array}$ & $\begin{array}{c}\text { Sensory deprivative } \\
\text { amblyopia } \\
\text { No. }=10\end{array}$ & $\begin{array}{c}\text { Test } \\
\text { value }\end{array}$ & $\begin{array}{c}p- \\
\text { value }\end{array}$ & Sig. \\
\hline \multicolumn{8}{|l|}{ Nasal 3mm: } \\
\hline Mean \pm SD & $165.20 \pm 22.27$ & $197.10 \pm 46.91$ & $217.20 \pm 38.22$ & $187.80 \pm 44.39$ & 3.039 & 0.041 & $\mathrm{~S}$ \\
\hline Range & $126-213$ & $114-272$ & $146-266$ & $133-290$ & & & \\
\hline \multicolumn{8}{|l|}{ Nasal $1 \mathrm{~mm}$ : } \\
\hline Mean \pm SD & $262.00 \pm 38.34$ & $317.20 \pm 76.28$ & $328.70 \pm 34.35$ & $315.30 \pm 47.68$ & 3.306 & 0.031 & $\mathrm{~S}$ \\
\hline Range & 202-339 & $200-470$ & $267-397$ & $210-378$ & & & \\
\hline \multicolumn{8}{|l|}{ Subfoveal: } \\
\hline Mean \pm SD & $309.70 \pm 39.77$ & $362.50 \pm 72.61$ & $399.00 \pm 32.11$ & $353.10 \pm 56.51$ & 4.866 & 0.006 & HS \\
\hline Range & $238-363$ & $243-511$ & $324-437$ & $230-415$ & & & \\
\hline \multicolumn{8}{|l|}{ Temporal $1 \mathrm{~mm}$ : } \\
\hline Mean \pm SD & $288.20 \pm 44.90$ & $335.20 \pm 78.01$ & $361.30 \pm 22.40$ & $335.80 \pm 49.49$ & 3.363 & 0.029 & $\mathrm{~S}$ \\
\hline Range & $213-341$ & $232-501$ & $313-386$ & $240-389$ & & & \\
\hline \multicolumn{8}{|l|}{ Temporal $3 \mathrm{~mm}$ : } \\
\hline Mean $\pm \mathrm{SD}$ & $268.70 \pm 39.28$ & $276.10 \pm 100.09$ & $317.70 \pm 22.44$ & $286.20 \pm 43.85$ & 1.331 & 0.279 & NS \\
\hline Range & $202-318$ & $146-501$ & $282-363$ & $238-361$ & & & \\
\hline
\end{tabular}

$p$-value $>0.05$ : Non significant (NS).

$p$-value $<0.05$ : Significant $(\mathrm{S})$.

$p$-value $<0.01$ : Highly significant (HS)

$\bullet:$ One Way ANOVA test. 
Table (7): Comparison between control group and patients' group regarding mean FAZ ( $\mathrm{mm}^{2}$ ) area in SCP and DCP.

\begin{tabular}{|c|c|c|c|c|c|}
\hline & $\begin{array}{l}\text { Control group } \\
\text { No. }=10\end{array}$ & $\begin{array}{c}\text { Strabismic } \\
\text { amblyopia } \\
\text { No. }=10\end{array}$ & $\begin{array}{c}\text { Anisometropic } \\
\text { amblyopia } \\
\text { No. }=10\end{array}$ & $\begin{array}{l}\text { Sensory deprivative } \\
\text { amblyopia } \\
\text { No. }=10\end{array}$ & $\begin{array}{c}p- \\
\text { value }\end{array}$ \\
\hline \multicolumn{6}{|l|}{$S C P:$} \\
\hline Mean \pm SD & $0.29 \pm 0.05$ & $0.35 \pm 0.12$ & $0.33 \pm 0.10$ & $0.31 \pm 0.04$ & 0.412 \\
\hline Range & $0.17-0.35$ & $0.19-0.5$ & $0.22-0.5$ & $0.25-0.39$ & \\
\hline \multicolumn{6}{|l|}{$D C P:$} \\
\hline Mean \pm SD & $0.23 \pm 0.05$ & $0.27 \pm 0.11$ & $0.30 \pm 0.08$ & $0.25 \pm 0.05$ & 0.154 \\
\hline Range & $0.14-0.28$ & $0.18-0.46$ & $0.19-0.41$ & $0.15-0.32$ & \\
\hline
\end{tabular}

$p$-value $>0.05$ : Non significant (NS).

$p$-value $<0.05$ : Significant $(\mathrm{S})$.

$p$-value $<0.01$ : Highly significant (HS).

\section{OCT-A data (Table 7) (Fig. 2):}

Mean FAZ area in SCP:

Comparison was done between the control group and patients' group regarding mean FAZ area in SCP and revealed that there was a no statistically significant difference ( $p$-value was 0.0412).

\section{Mean FAZ area in DCP:}

Comparison was done between the control group and patients' group regarding mean FAZ area in DCP and revealed that there was no statistically significant difference ( $p$-value was 0.154 ).
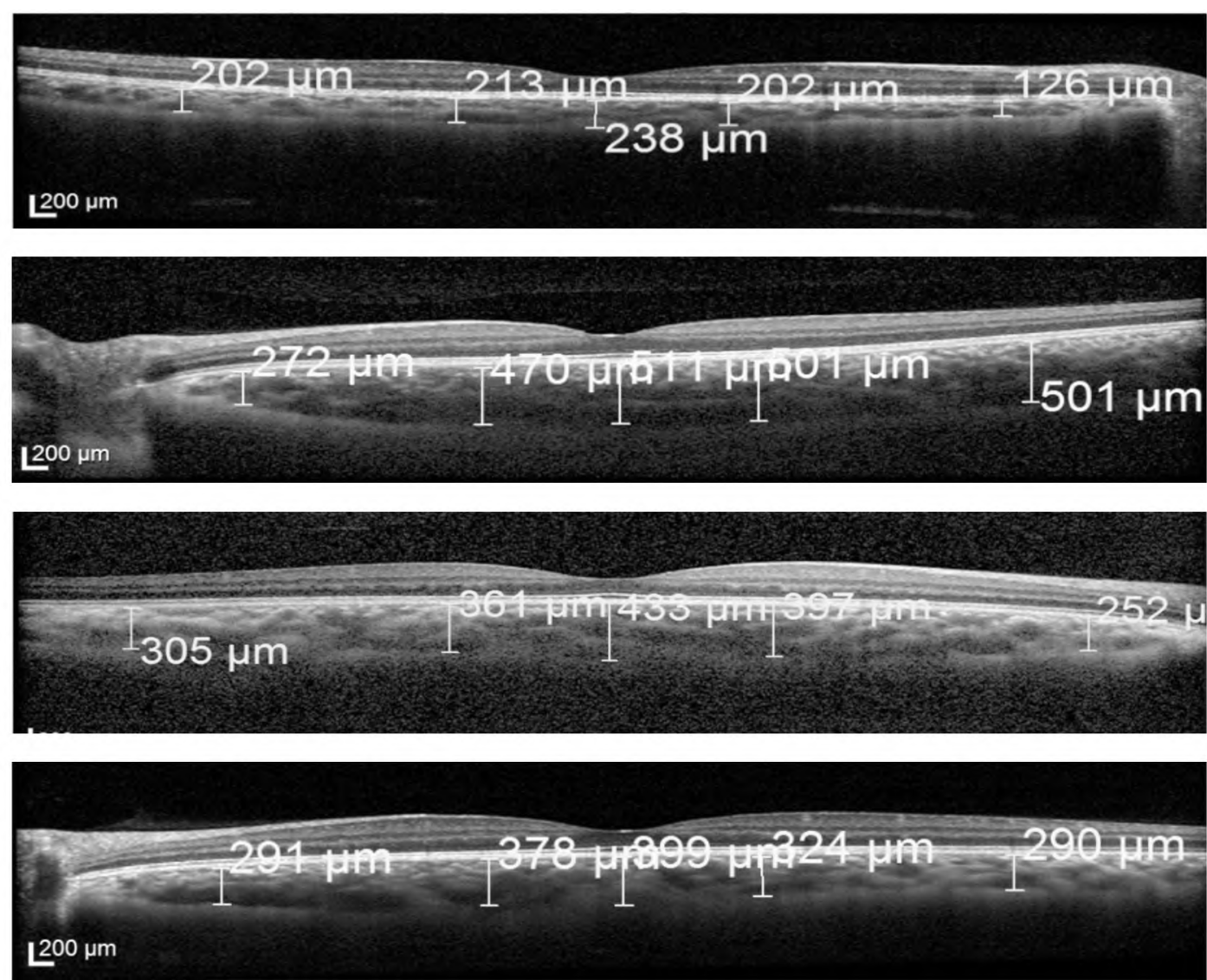

Fig. (1): Choroidal thickness (A) Control (RT eye), (B) Strabismic (LT eye), (C) Anisometropic (RT eye), (D) Sensory deprivative (LT eye). 

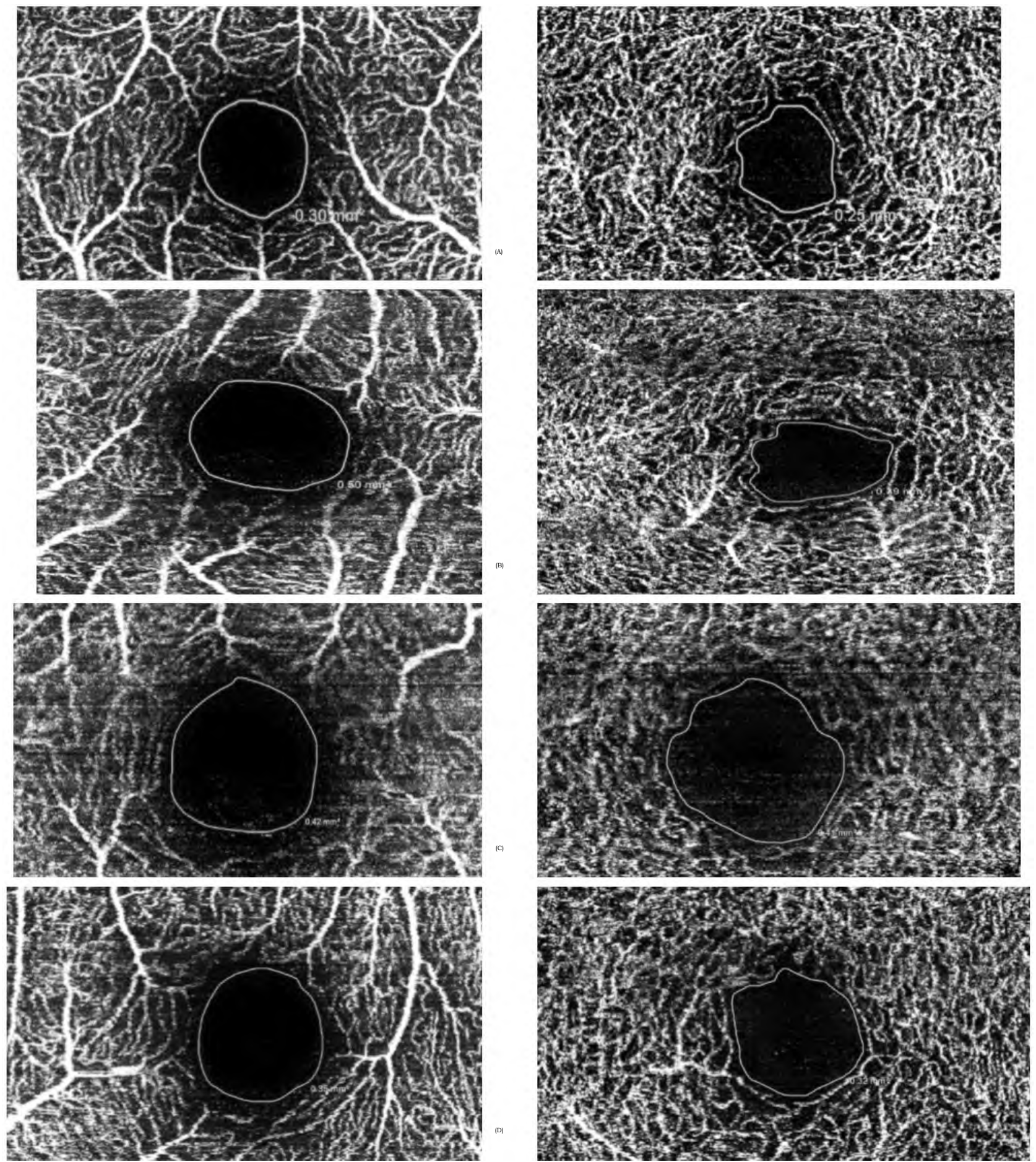

Fig. (2): FAZ in SCP (Left) and DCP (Right) of (A) Control (B) Strabismic amblyopia, (C) Anisometropic amblyopia (D) Sensory deprivative amblyopia.

\section{Discussion}

For many years, amblyopia has been considered a disorder of the visual system that represents unilateral or bilateral reduction of visual acuity in which an organic cause could not be detected [8]

New horizons in understanding the etiopathology of amblyopia are offered by OCT which seems to highlight morphologic anomalies in the retina of the amblyopic eye [9]. A series of studies that aimed to analyse macular thickness, optic nerve morphology and also choroidal thickness in the amblyopic eye have been published in the last years. The results are often contradictory because, when conducting an OCT in patients with anisometropia it is important to correct the magnifi- 
cation of the device according to refraction and axial length of the eye. Also, results differ depending on the device used [9]. Another limitation regarding accurate interpretation of OCT in children emerges from the inexistence of international established normative values of macular and RNFL parameters in children [10].

OCTA is a new and non-invasive method of retinal and optic nerve head imaging based on high resolution analysis. No dye is required to visualize the microvascular network, because the movement of blood cells provides contrast [11]. OCTA obtains blood flow and density in a repeatable and reproducible manner [12], achieving volumetric angiograms with structural and functional vascular information and the possibility of segmentation at different depths [13]

\section{Regarding macular thickness:}

In this study on comparing control group and patients' groups as regards mean total macular thickness in the central $(1 \mathrm{~mm})$ and in the four quadrants (at $3 \mathrm{~mm}$ and $6 \mathrm{~mm}$ ) we found the following:

For the sensory deprivative group there was significantly thicker central macular thickness $(1 \mathrm{~mm})$ with ( $p$-value 0.033$)$ and no statistically significant difference in four quadrants of macular thickness (at $3 \mathrm{~mm}$ and $6 \mathrm{~mm}$ ) with ( $p$-value $>0.05$ ). This was similar to a study conducted by Kasem and Badawi, 2017 on 12 amblyopic patients (sensory deprivation), they found that central macular thickness showed a significant variance between the amblyopic eyes and the fellow eyes $(p=0.021)$, while the average macular thickness showed an insignificant difference ( $p$-value $>0.05)$ [14]

In our study, for the strabismic and anisometropic groups there was no statistically significant difference in mean central macular thickness and macular thickness in four quadrants $(3 \mathrm{~mm}$ and $6 \mathrm{~mm})$ ( $p$-values were $>0.05$ ). And this was consistent with a study conducted by Araki et al., 2014 and Araki et al., 2017 [15,16]

In contrast, $\mathrm{Al}$ Haddad et al., 2011 found that the central macular thickness was significantly increased in amblyopic eyes as compared to that of the fellow eyes in anisometropic amblyopia, but not in strabismic amblyopia [17]. Park et al., 2011 additionally reported finding no statistically significant differences in the total macular thickness between the amblyopic and normal fellow eyes in unilateral amblyopia, with these eyes also showing no significant differences in the refractive errors. Based on these findings, they believed that it is possible that a change in the macular thickness of amblyopic eyes relates to refraction [18]. However, Al Haddad et al., 2011 also reported that anisometropia alone did not lead to such a difference, which suggests that there could possibly be a correlation between amblyopia and the development of the retinal layers [17].

\section{Regarding ganglion cell layer thickness:}

This study found that there was no statistically significant difference on comparing GCL thickness between control group and amblyopic groups with ( $p$-value $>0.05)$.

That was similar to two studies conducted by Araki et al., 2014 and Araki et al., 2017 they found that there was no significant difference in GCL thicknesses among the strabismic, anisometropic amblyopic patients and control eyes with ( $p$-value $>0.05)[15,16]$

Also Kim et al., 2013 conducted a study on 14 unilateral pseudophakic children with deprivational amblyopia. They stated that there was no statistically significant difference on comparing GCL in sensory deprivative group ( $p$-value >0.05) [9]

On the other hand, Park et al., 2011 reported that the GCL-IPL thickness was thinner in amblyopic eyes than in fellow eyes [18]. In contrast, Tugcu et al., 2013 found that the GCC thickness was thicker in amblyopic eyes than in controls [19] The causes of these differences in results may be related to factors in the study design, such as which structures were measured; for example, whether the nerve fiber layer thickness was included in the inner retinal thickness. Additionally, that heterogeneity of the SD-OCT model that was used for the study is one of the factors to cause the different results [19].

\section{Regarding retinal nerve fiber layer:}

Comparison between control group and patients' group was done regarding RNFL thickness and revealed non statistically significant difference in all quadrants in patients with anisometropic amblyopia, also in strabismic and deprivative groups there was no statistically significant difference in superior, inferior and temporal quadrants ( $p$-value $>0.05$ ). And statistically significant less thickness in nasal quadrant in strabismic and sensory deprivative groups ( $p$-value $0.011, p$-value 0.015 respectively).

Kim et al., 2013 conducted a study on 14 unilateral pseudophakic children with deprivational amblyopia, and 14 age matched normal children, they found no significant difference in superior, 
inferior and temporal quadrants ( $p$-value $>0.05$ ) that was similar to our study but, their study found that nasal RNFL thickness was significantly greater in amblyopic eyes than in normal eyes $(p=0.037)$ [9].

Another study for sensory deprivational amblyopia conducted by Bansal et al., 2016. They found that the patients with unilateral cataract showed significant thinning of superior, nasal, and temporal RNFL compared to the fellow eyes as well as age matched normal eyes. In bilateral cataract, there was statistically significant thinning of RNFL in superior and nasal quadrants as compared to age matched normal eyes [20].

For anisometropic group Araki et al., 2017 stated that there was no statistically significant difference in superior, inferior, nasal and temporal quadrants $(p$-value $>0.05)$ that was consistent with our study [16] .

For anisometropic and strabismic groups a study conducted by Atakan et al., 2015 on 61 amblyopic (30 strabismic, 31 anisometropic), the RNFL was found thinner in anisometropic group compared to control eyes, and there was no statistically significant difference were found in all values between groups $(p>0.05)$, that was similar to our study [21]. For strabismic group they found that RNFL was slightly thicker comparing to control group, but not significantly different. That was in contrast to our study that found non significant difference in all quadrants except nasal quadrant that was significant smaller in comparison to control group $(p$-value $=0.011)[21]$

\section{Regarding choroidal thickness:}

Our study found that there was significantly greater choroidal thickness at nasal $(1 \mathrm{~mm}$ and $3 \mathrm{~mm}$ ), sub-foveal and temporal $1 \mathrm{~mm}$ ( $p$-value $<0.05$ ) and non-significant difference at temporal $3 \mathrm{~mm}$ on comparing anisometropic group with control ( $p$-value >0.05). Regarding strabismic group it was significantly greater at nasal $1 \mathrm{~mm}$ and sub-foveal, non-significant difference at nasal $3 \mathrm{~mm}$ and temporal $1 \mathrm{~mm}, 3 \mathrm{~mm}$.

Tenlik et al., 2014 conducted a study on total 53 subjects with hyperopic anisometropic amblyopia and 53 age-matched controls were included in this prospective study. Their study stated that choroidal thickness shows significance difference (thicker) ( $p$-value $<0.001)$ in all sectors including temporal $3 \mathrm{~mm}$ that was in contrast to our study that found no significance difference in temporal $3 \mathrm{~mm}$ regarding anisometropic group [22].
Another study conducted by Aygit et al., 2015 on 40 patients with anisometropic amblyopia, 40 patients with strabismic amblyopia and 40 agematched controls. In agreement to our results they found that subfoveal choroidal thickness of both anisometropic and strabismic amblyopic eyes were significantly thicker than that of the fellow eyes of the corresponding groups and the control eyes $(p<0.05$ for all). But in contrast to our study they found non significance difference at $1 \mathrm{~mm}$ nasal (232).

It is believed that the choroid plays a role in emmetropization and refractive error development. Previous studies have established that a variety of young animals undergo rapid changes in choroidal thickness in response to imposed defocus to adjusts the position of the retina and maintain clear vision [24].Therefore, Aygit et al., 2015 extrapolated that in amblyopic eyes, this choroidal compensation does not occur, explaining why choroidal thickness was thicker than in fellow eyes and the normal control eyes.

To our knowledge our study is the first study on sensory deprivation regarding choroidal thickness. We found significantly greater choroid thickness at $1 \mathrm{~mm}$ nasal and temporal ( $p$-value $<0.05$ ), non significant difference at $3 \mathrm{~mm}$ temporal, $3 \mathrm{~mm}$ nasal and sub-foveal ( $p$-value $>0.05$ ).

\section{Regarding SCP and DCP:}

Comparison was done between the control group and patients' group regarding mean FAZ area in SCP and DCP. Our study found that the FAZ in both SCP and DCP was larger but not statistically significant ( $p$-value was $0.0412 \&$ $0.154)$ respectively.

Sobral et al., 2018 conducted a similar study on total of 52 children, 26 in the amblyopic group and 26 in the control group. In the amblyopic group, 16 children had strabismic amblyopia and 10 had anisometropic amblyopia. In subjects, the mean area of FAZ of the SCP was higher in the amblyopic eye than in the control eye, although the difference did not reach statistical significance $(p=0.2104)$. The FAZ area of the DCP was also larger in the amblyopic eye than the contralateral eye, again not reaching statistical significance $(p=0.0907)$ [25]

Another study conducted by Miki et al., 2019 stated that the mean area of FAZ of the SCP and DCP was smaller in the amblyopic eye than in the control eyes, this was in contrast to our study that was larger but it also did not reach statistical significance $(p>0.05)$ [26]. 
To our knowledge our study is the first study on sensory deprivation regarding FAZ area in SCP and DCP, we found that the FAZ in both SCP and DCP was higher but not statistically significant ( $p$-value >0.05).

Our study was limited by small sample size. Further researches including larger sample size are needed for more evaluation of OCT and OCTA findings in amblyopic patients.

\section{Conclusion:}

Patients with unilateral amblyopia were prone to have a higher central macular thickness in sensory deprivative group only, with no difference in thickness regarding strabismic and anisometropic groups, while there was thinner nasal quadrant RNFL thickness in strabismic and sensory deprivative groups only, when compared to control eyes. Also there was significant increase in sub-foveal choroidal thickness in strabismic and anisometropic group with no difference in sub-foveal thickness in sensory deprivative group. Regarding GCL and (SCP, DCP) in FAZ area there was no significant difference between amblyopic groups and control group.

Further studies are needed on larger number of patients to evaluate the results of OCT and OCTA findings in amblyopic patients.

\section{References}

1- TAILOR V., GREENWOOD J. and DAHLMANN-NOOR A.: Childhood amblyopia: Current management and new trends. Br. Med. Bull., 119 (1): 75-86, 2016.

2- KARABULUT M., KARABULUT S., SÜL S. and KARALEZLI A.: Microvascular changes in amblyopic eyes detected by optical coherence tomography angiography. Journal of American Association for Pediatric Ophthalmology and Strabismus, 23 (3): 155-e1, 2019.

3- BITIRGEN G., DARAGHMA M. and ÖZKAGN1C1 A.: Evaluation of Pupillary Light Reflex in Amblyopic Eyes Using Dynamic Pupillometry. Turkish Journal of Ophthalmology, 49 (6): 310, 2019.

4- RAJAVI Z., SABBAGHI H., BEHRADFAR N., YASERI M., AMIRI M. and FAGHIHI M.: Macular thickness in moderate to severe amblyopia. Korean Journal of Ophthalmology: KJO, 32 (4): 312, 2018.

5- KASHANI A., CHEN C., GAHM J., ZHENG F., RICHTER G., ROSENFELD P. and WANG R.: Optical coherence tomography angiography: A comprehensive review of current methods and clinical applications. Progress in retinal and eye research, 60: 66-100, 2017.

6- CHENG Y., GUO L., PAN C., LU T., HONG T., DING Z. and LI P.: Statistical analysis of motion contrast in optical coherence tomography angiography. Journal of Biomedical Optics, 20 (11): 116004, 2015.
7- De OLIVEIRA P., BERGER A. and CHOW D.: Optical coherence tomography angiography in chorioretinal disorders. Canadian Journal of Ophthalmology, 52 (1): 125136, 2017.

8- AVRAM E. and STANILA A.: Functional amblyopia. Oftalmologia (Bucharest, Romania: 1990), 57 (4): 3-8, 2013.

9- KIM Y., KIM S. and YU Y.: Spectral-domain optical coherence tomography analysis in deprivational amblyopia: a pilot study with unilateral pediatric cataract patients. Graefe's Archive for Clinical and Experimental Ophthalmology, 251 (12): 2811-2819, 2013.

10- MOLNAR A., HOLMSTRÖM G. and LARSSON E.: Macular thickness assessed with spectral domain OCT in a population-based study of children: Normative data, repeatability and reproducibility and comparison with time domain OCT. Acta ophthalmologica, 93 (5): 470475,2015 .

11- GAO S., JIA Y., ZHANG M., SU J., LIU G., HWANG T. and HUANG D. Optical coherence tomography angiography. Investigative ophthalmology \& visual science, 57 (9): 27-36, 2016.

12- CHEN C., BOJIKIAN K., XIN C, WEN J., GUPTA D., ZHANG Q. and WANG: Repeatability and reproducibility of optic nerve head perfusion measurements using optical coherence tomography angiography. Journal of biomedical optics, 21 (6): 065002, 2016.

13- JIA Y., MORRISON J., TOKAYER J., TAN O., LOMBARDI L., BAUMANN B. and HUANG D.: Quantitative OCT angiography of optic nerve head blood flow. Biomedical optics express, 3 (12): 3127-3137, 2012.

14- KASEM M. and BADAWI A.: Changes in macular parameters in different types of amblyopia: Optical coherence tomography study. Clinical Ophthalmology, 11: 1407, 2017.

15-ARAKI S., MIKI A., YAMASHITA T., GOTO K., HARUISHI K., IEKI Y. and KIRYU J.: A comparison between amblyopic and fellow eyes in unilateral amblyopia using spectral-domain optical coherence tomography. Clin. Ophthalmo., 8: 2199-207, 2014.

16- ARAKI S., MIKI A., GOTO K., YAMASHITA T., TAKIZAWA G., HARUISHI K. and YAOEDA K.: Macular retinal and choroidal thickness in unilateral amblyopia using swept-source optical coherence tomography. BMC ophthalmology, 17 (1): 1-13, 2017.

17- AL-HADDAD C., MOLLAYESS G., CHERFAN C., JAAFAR D. and BASHSHUR Z.: Retinal nerve fibre layer and macular thickness in amblyopia as measured by spectral-domain optical coherence tomography. Br. J. Ophthalmol., 95: 1696-9, 2011.

18- PARK K., PARK D.Y. and OH S.Y.: Analysis of spectraldomain optical coherence tomography measurements in amblyopia: A pilot study. Br. J. Ophthalmol., 95 (12): 1700-1706, 2011.

19- TUGCU B., ARAZ-ERSAN B., KILIC M., ERDOGAN E., YIGIT U. and KARAMURSEL S.: The morphofunctional evaluation of retina in amblyopia. Curr. Eye Res., 38 (7): 802-809, 2013.

20- BANSAL P., RAM J., SUKHIJA J., SINGH R. and GUPTA A.: Retinal nerve fiber layer and macular thickness 
measurements in children after cataract surgery compared with age-matched controls. American Journal of Ophthalmology, 166: 126-132, 2016.

21- ATAKAN M., CULFA S., CALLI U., PENBE A., ATAKAN T. and ÖZERTÜRK Y.: Evaluation of retinal nerve fibre layer and macular thickness in amblyopia. J. Clin. Exp. Ophthalmol., 6 (437): 2, 2015.

22- TENLIK A., GÜLER E., KULAK A., TOTAN Y., DERVIS OGULLAR1 M. and GÜRAG AÇ F.: Evaluation of choroidal thickness in amblyopia using enhanced depth imaging optical coherence tomography. Current eye research, 40 (10): 1063-1067, 2015.

23- AYGIT E., YILMAZ I., OZKAYA A., ALKIN Z., GOKYIGIT B., YAZICI A. and DEMIROK A.: Choroidal thickness of children's eyes with anisometropic and strabismic amblyopia. Journal of American Association for
Pediatric Ophthalmology and Strabismus, 19 (3): $237-$ $241,2015$.

24- ZHU X. and WALLMAN J.: Temporal properties of compensation for positive and negative spectacle lenses in chicks. Invest Ophthalmo. Vis. Sci., 50: 37-46, 2009.

25- SOBRAL I., RODRIGUES T., SOARES M., SEARA M., MONTEIRO M., PAIVA C. and CASTELA R.: OCT angiography findings in children with amblyopia. Journal of American Association for Pediatric Ophthalmology and Strabismus, 22 (4): 286-289, 2018.

26- MIKI A., ARAKI S., GOTO K., YAMASHITA T., YONEDA T., HARUISHI K. and YAOEDA K.: Evaluation of foveal avascular zone and macular vessel density in unilateral amblyopia using optical coherence tomographic angiography. Investigative Ophthalmology \& Visual Science, 60 (9): 209-209, 2019.

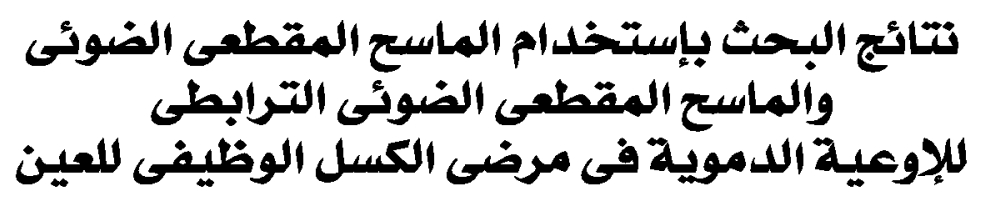

المقدمة: الكسل الوظيفى للعين هو انخفاض في حدة الإبصار في عين واحدة أو العينين نتيجة للحرمان من الرئية بالعينين أو اختلال المحاود البصرية للعينين مع علم وجود سبب ظاهرى بالفحص الإكلينيكى للعين وفى بعض الحالات يمكن علاجه بطرق علاجية مختلة.

الهدف من البحث: فحص العيون المصابة بالكسل الوظيفى لأسباب مختلفة بإستخدام الماسع المقطعى الضوئى الترابطى والماسح

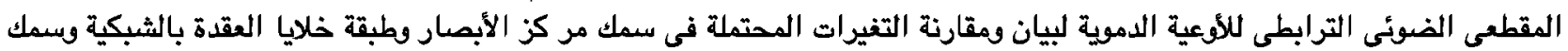

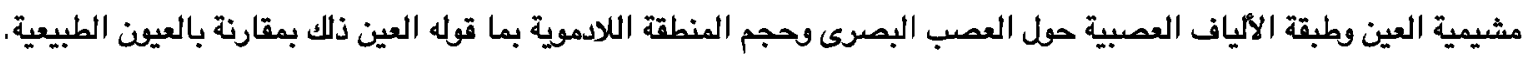

نوع الدراسة ووسائل وطرق البحث: دراسة مقارثة. أجريت على أربعفن عيناً من أربعين مشاركاً مقسمة إلى أربعة مجموعات .ب مرضاً

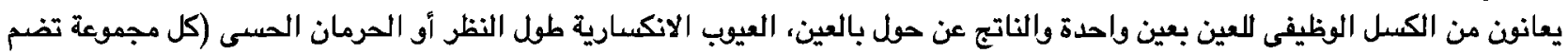

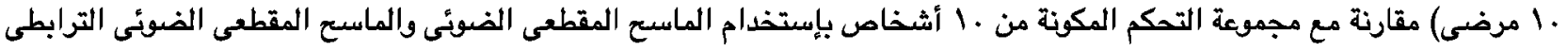
لالأوعية الدموية.

النتائج: فيما يتعلق بمتوسط سماكة طبقة خلايا العقدة والمنظقة اللادموية بالماقولة، لم يكن هناك فرق ذو دلالة إحصائية بين مجموعات

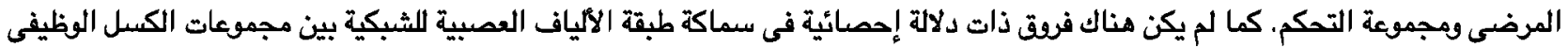

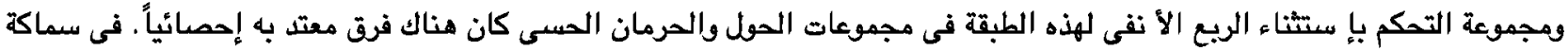

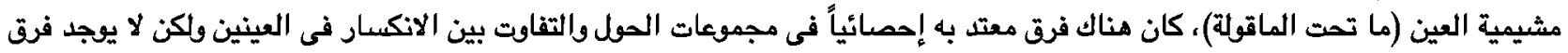

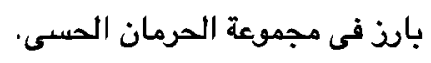

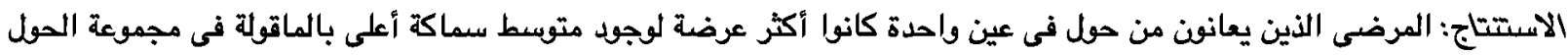

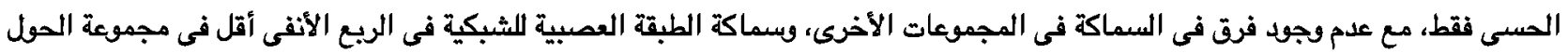

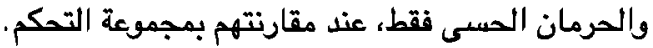

